\title{
4
}

\section{International law and humanitarian intervention}

\section{Advocates and opponents of humanitarian intervention}

From the 1860 o onwards, international law became an academic discipline in its own right in Europe and the Americas, taught separately from philosophy, natural law or civil law, and came to be written by professional academics or theoretically inclined diplomats. ${ }^{1}$ Until then what existed was the droit public de l'Europe or 'external public law'. Britain in particular had to face the 'spectre of Austin', ${ }^{2}$ who dominated British jurisprudence in the first part of the nineteenth century. For John Austin, 'laws properly so called' were 'established directly by command'3 and those lacking command were 'positive moral rules which are laws improperly so called ... laws set or imposed by general opinion' ${ }^{4}$ and this was the case with the 'so called law of nations [which] consists of opinions or sentiments current among nations generally'.

Two landmarks for international law are the founding of its first scholarly journal and of an institute/association of international lawyers (see chapter 3 ). The journal, the Revue de droit international et de législation comparée, was launched in Belgium in 1868, by the Belgian Gustave Rolin-Jaequemyns, the Dutch Tobias Asser and the British John Westlake, with the support of the Italian Professor Pasquale Mancini. ${ }^{6}$ Rolin-Jaequemyns was also at the forefront of the creation of the Institut de droit international in 1873, with the help of Bluntschli, Holtzendorff, Calvo, Mancini and a few others.?

At its inception, the ultimate aim of the Institut was ' $[\mathrm{d}] \mathrm{e}$ favoriser le progrès du droit international, en s'efforçant de devenir l'organe de la conscience juridique du monde civilisé'. ${ }^{8}$ The wording in question had come from Bluntschli, who had used such language before in his publications. ${ }^{9}$ As Martti Koskenniemi points out, the reference to 'legal conscience', or 'consciousness', seems to us today 'oldfashioned and difficult to take in full seriousness. ${ }^{10}$ But in those days this aim was taken in all seriousness and voiced by worldly publicists, many of them with hands-on experience as politicians, diplomats, lawyers or judges.

Interestingly, humanitarian intervention entered the scene as international law was developing into a scientific discipline, as in the case of another science in 
its modern form, history, which matured hand in hand with the rise of nationalism (hence the emergence of national historiography in the nineteenth century). ${ }^{11}$

From the 1830 s until the 1930 most publicists addressed the question of intervening or not for humanitarian purposes to stop 'the effusion of blood', with a clear majority favouring the use of armed force for humanitarian purposes in certain exceptional cases, thereby bypassing the cardinal norm of non-intervention (see table 4.1). According to Wilhelm Grewe's assessment, in the nineteenth century 'the principle of humanitarian intervention increasingly absorbed all other grounds of intervention (with the exception of contractual permission and selfhelp)'. ${ }^{12}$ This tendency in law and practice is striking, for, prior to the UN Charter and the international law of human rights, there was no international legal ban on acts of inhumanity by states, and sovereignty and independence, including the norm of non-intervention, were the cornerstones of international law. On the other hand, aggressive war was permitted and was a manifestation of sovereignty. ${ }^{13}$ The 'paradoxical outcome' was that 'the greater threat to the integrity of states (waging war) was widely regarded as legitimate, but the lesser (intervention) was not '; ${ }^{14}$ thus, 'in the absence of a clear distinction between intervention and war any regulation of the former could be circumvented by resort to the latter.' ${ }^{15}$

There was also the parallel development of the laws of war aimed at humanizing warfare initiated by Henry Dunant in the wake of the suffering in the Crimean War and the 1859 Battle of Solferino during the Second Italian War of Independence. ${ }^{16}$ The laws of warfare were the first branch of international law to be codified ${ }^{17}$ and these mention the concept of 'humanity'. The 1899 and 1907 Hague Conventions on land warfare adopted, in 'the interests of humanity', what came to be known as the 'Martens clause', proposed by F. F. Martens, 'that in cases not included in the Regulations adopted ... the inhabitants and the belligerents remain under the protection and the rule of the principles of international law, as they result from the usages established among civilized peoples, from the laws of humanity, and the dictates of the public conscience'. Thus, at the turn of century, the humanitarian idea had entered general international law. ${ }^{18}$

The advocates of humanitarian intervention, within a period of about a century, from the 1830 s to the 1930s, regarded it as legitimate, but only if it fulfilled the following criteria: (1) intervention was needed to counter gross mistreatment and massacres 'shocking the moral consciousness of mankind', (2) the intervention was collective or quasi-collective, so as to acquire international legitimacy and limit the abuse factor; and (3) disinterestedness or that humanitarian concern was one of the main motives and justifications for intervening. ${ }^{19}$

Those opposed to such interventions based their case on the principles of sovereignty and independence, with non-intervention as their corollary, as well as on practical grounds, especially abuse by powerful states, with total disinterestedness regarded as unrealistic and by definition bogus. Some also alluded to the double standard of singling out only 'barbarous' states for intervention. 
We have identified no less than 100 publicists who had addressed the question from the 1830 s up to the 1930s, mainly with the historical examples of the nineteenth century in mind. ${ }^{20}$ Sixty-two were supportive of humanitarian intervention (that is, 62 per cent of the total). Of the publicists supportive of armed humanitarian intervention, forty-eight claimed a right to intervene in exceptional circumstances only and fourteen invoked moral or political reasons. There is also a substantial minority against any such legal or moral right: thirty-eight publicists (that is, 38 per cent of the total) (see table 4.1$){ }^{21}$

To make our presentation as lucid as possible, we will divide our material into five periods, from the 1830 s until the 1930s, and present it, to the degree possible, in the form of a debate.

\section{0-50: from Wheaton to Heffter}

In the 1830 s and 1840 os, eleven publicists addressed the question, more or less equally divided into advocates and opponents of humanitarian intervention (see table 4.1).

In the first decades of the twentieth century, Egide Arntz, of the University of Brussels, was credited as the first to formulate the theory of humanitarian intervention, this in the mid-187os. ${ }^{22}$ Arntz's thesis was presented in a letter he sent to Rolin-Jaequemyns, which the latter published in the Revue. ${ }^{23}$ But most commentators in the second part of the nineteenth and today regard Wheaton as the initiator of the concept, on the basis of the following statement, made a few years after the end of the Greek independence struggle, in his 1836 treatise: ${ }^{24}$

The interference of the Christian powers of Europe, in favor of the Greeks, who, after enduring ages of cruel oppression, had shaken off the Ottoman yoke, affords a further illustration of the principles of international law authorizing such an interference, not only where the interests and safety of other powers are immediately affected by the internal transactions of a particular state, but where the general interests of humanity are infringed by the excesses of a barbarous and despotic government.

Wheaton's view on intervention was put to task by the Italian-French jurist, economist and politician Pellegrino Rossi and by the British lawyer and economist Nassau William Senior. Rossi advocated neutrality in civil wars, save when a neighbouring state was menaced by the conflict. ${ }^{25}$ Senior, a frequent writer on political affairs and governmental adviser, commented that 'interference for the mere purpose of preventing the oppression of Subjects by their Prince' was unlawful ${ }^{26}$ and dangerous, and made the lasting point that it was 'the privilege ... of the strong against the weak'. ${ }^{27}$

In the 1840s, three advocates of non-intervention allowed for a slight opening for exceptional intervention in instances of humanitarian plight. The Norwegian 


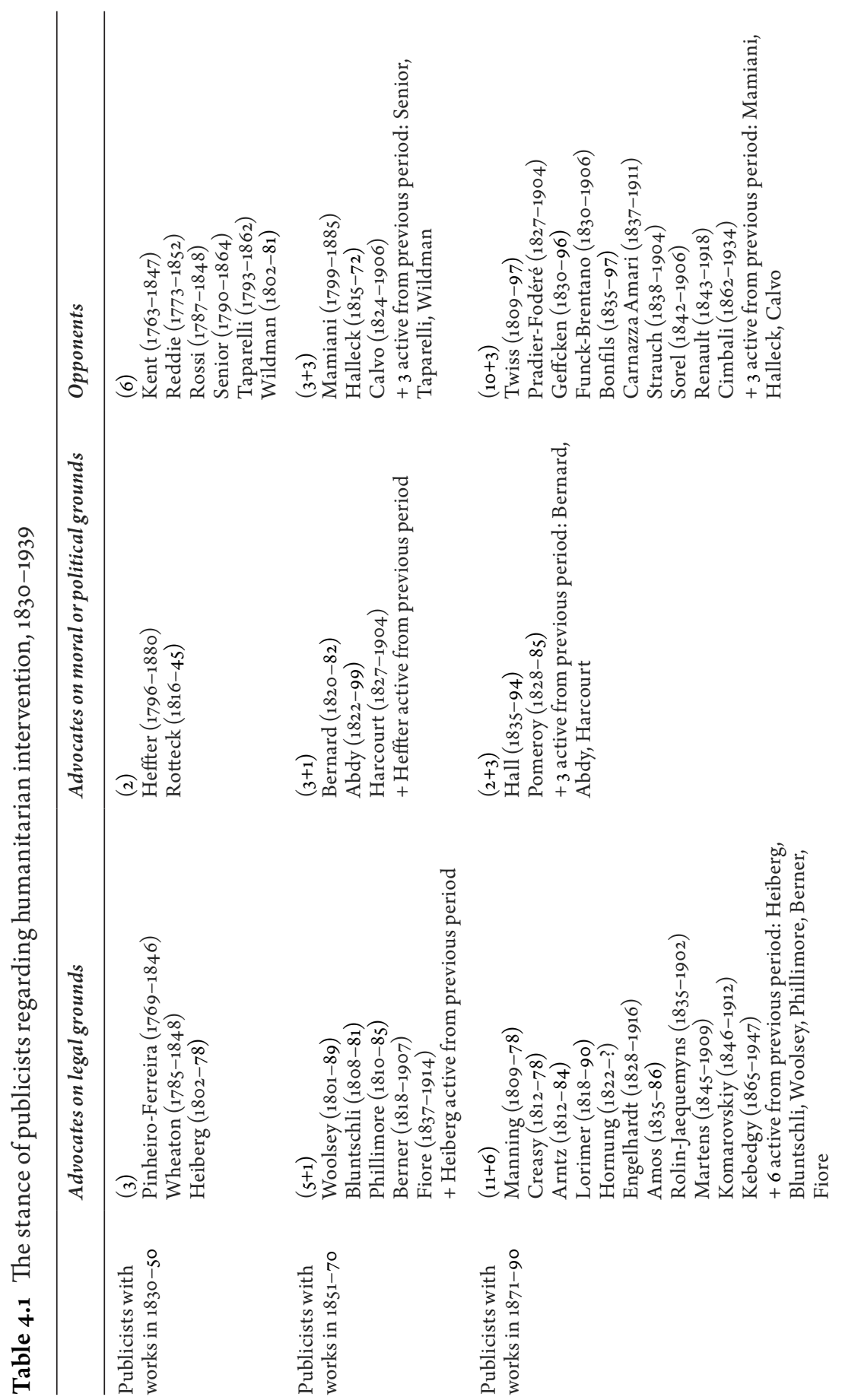



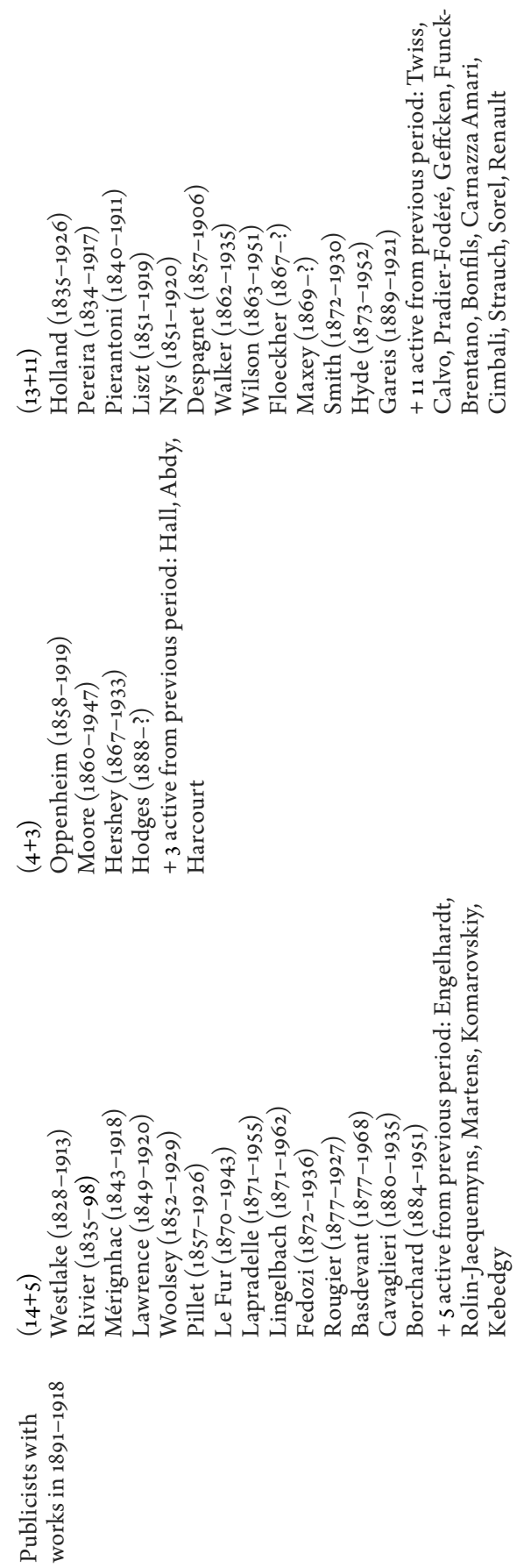

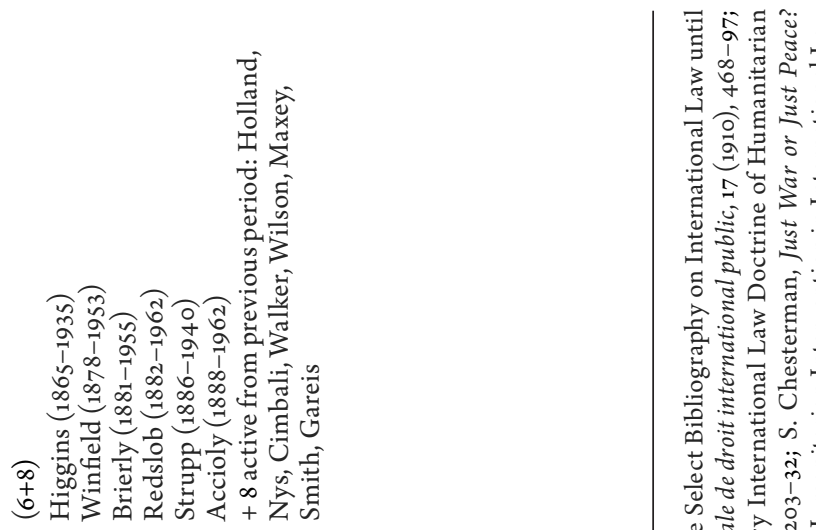

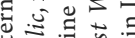

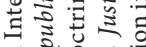

ธ

를.

당 정

을 워

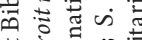

to 0

过苛

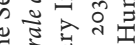

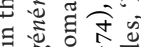

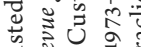

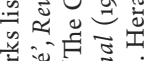

में

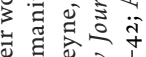

氖起 है

造记

ه

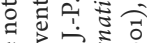

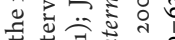

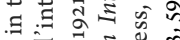

च च

कै

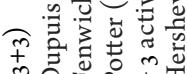

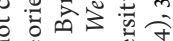

造

:

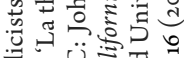

苛家可

范

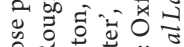

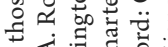

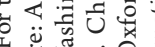

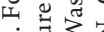

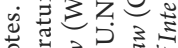

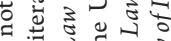

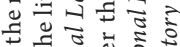

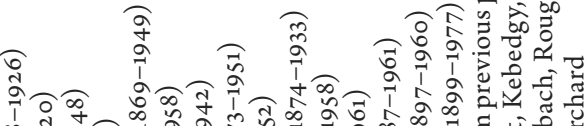

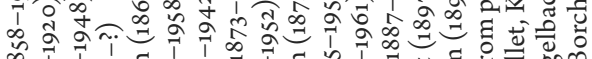
更

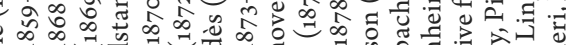

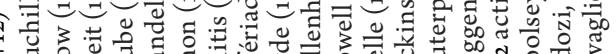

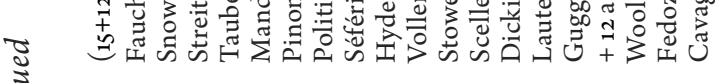

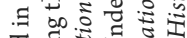

एक

पु.

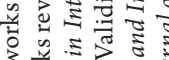

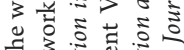

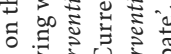

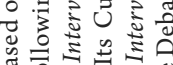
ऽ류. क ष

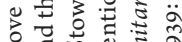
०े के है

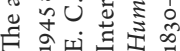


authority Johan Heiberg (in 1842) regarded intervention for humanity 'inevitable', when 'assured rights and reciprocally recognized principles' were 'endangered'. ${ }^{28}$ His German contemporary, Heffter, opined that nations 'have incontestably the right to put an end, after common consent, to a civil war which devours one or more countries' and this could also be done by 'armed interference'; ${ }^{29}$ he added that 'foreign powers can assist the party whose position seems to them to be founded on justice, if it invokes their help'. ${ }^{30}$ Herman Rodecker von Rotteck asserted that ' $[\mathrm{h}]$ umanitarian intervention should be considered as a violation of law, but sometimes excused, or even applauded, as we excuse a crime'. ${ }^{31}$

\section{1-70: from Phillimore, Woolsey and Mamiani to Fiore and Bluntschli}

In the 1850 and 1860 s at least eleven publicists addressed the question for the first time, with the supporters more than double the opponents, eight against three, and if to them we add those from the previous period who had not passed away (and presumably had not retracted their views), the numbers are ten as opposed to six jurists (see table 4.1).

In the mid-1850s, Phillimore argued that a limitation of the principle of nonintervention 'may possibly arise from the necessity of Intervention by Foreign Powers in order to stay the shedding of blood caused by a protracted and desolating civil war in the bosom of another State'. ${ }^{32}$ He regarded it as 'an accessory' to other factors and on its own not in the code of international law, 'since it is manifestly open to abuses'. ${ }^{33}$ Despite his misgivings he concluded that intervention by a Christian state 'on behalf of the subjects of another upon the ground of Religion' is not 'a violation of International Law ... as an armed Intervention to prevent the shedding of blood and protracted internal hostilities' ${ }^{34}$

In the US, the Yale Professor Theodore Dwight Woolsey maintained, in his 1860 treatise, that interference can be justified if 'brought about by the crime of a government against its subjects', ${ }^{35}$ adding that in the case 'of extraordinary crimes committed by a government against its subjects ... the danger of erring is less than in the other instances, because interference here is more disinterested; and the evil results of a mistake are less, because such cases are comparatively rare'. ${ }^{36}$ In the same year, Professor Albert Friedrich Berner of the University of Berlin asserted that there were reasonable exceptions to non-intervention, such as continued acts of inhumanity, for ' $[\mathrm{m}] \mathrm{an}$ is the highest right before which all other right must incline' ${ }^{37}$

The end of the 185 os saw one of the most elaborate rebuttals of humanitarian intervention, by Terenzio Mamiani. After a detailed presentation of the various reasons for intervention he concluded that 'all forcible intervention in the internal affairs of a people is to be deemed unjust and oppressive. ${ }^{38}$ As he put it, ' $[\mathrm{t}$ ] he doings or misdoings of a people ... within the bounds of its own territory, and without detriment to others' rights, never afford any ground for legitimate intervention'. ${ }^{39}$ 
However, Mamiani allowed for two exceptions to non-intervention, which he did not associate with intervention in humanitarian plights: (1) intervention when a war was waged by a subject people; ${ }^{40}$ and (2) 'opposing the wrongful intervention of others, and undoing the certain and immediate effects which it has induced', ${ }^{41}$ that is, counter-intervention.

Mountague Bernard, the first Professor of International Law in Britain, occupant of the newly created Chichele Chair of International Law and Diplomacy at Oxford University, is hard to pinpoint. In a lecture at All Souls College at Oxford University on the principle of non-intervention, he argued against intervention, referring extensively to Mamiani's arguments. ${ }^{42}$ But then he made an about-face by distinguishing between 'rebellion' and 'revolt', defining the former as successful change of government or dynasty and the latter as the splitting of a state into two parts. He claimed that in the latter case 'interference ceases to be intervention when this is done', as in the case of the Battle of Navarino during the Greek War of Independence (see chapter 6), which could not be seen as 'simply an intervention in the internal affairs of the Turkish empire'. ${ }^{43}$ Another remark by Bernard makes his overall position even more baffling: that 'for the protection of the weak ... there may be the most powerful inducements to shake off the restraints of the rule [of non-intervention]. Nay, there may even be cases in which it becomes a positive duty to transgress it'. ${ }^{4}$

Henry Wager Halleck, an American Civil War general better known as a jurist, maintained that interference on humanitarian grounds was lawful only if it amounted to 'pacific mediation', that is, 'one State merely proposing its good offices for the settlement of the intestine [sic] dissensions of another State'. ${ }^{45}$

The important Liberal politician Sir William Vernon Harcourt, repeatedly cabinet minister under Gladstone and one-time Professor of International Law at Cambridge (the first occupant of the Whewell Chair in International Law), made the following oft-quoted remark: 'Intervention is a question rather of policy than of law. It is above and beyond the domain of law, and when wisely and equitably handled by those who have the power to give effect to it, may be the highest policy of justice and humanity'. ${ }^{46}$ But he cautioned: 'I am not insensitive to the respectable sentiments of humanity ... but I also know that, of all things, the most cruel is a mistaken and useless interference'. ${ }^{47}$

Pasquale Fiore, the leading Italian authority, criticized the publicists who remained indifferent spectators of the affairs of other countries if their interests were not directly threatened ${ }^{48}$ and added graphically (in 1865): ${ }^{49}$

Let us suppose ... that a prince, in order to quell a revolution, violates all the most recognized laws of war, kills the prisoners, authorizes plundering, rapine, arson, and encourages his supporters to commit those odious acts and others of the same kind.... The laissez-faire and indifference of other States constitutes an egoistic policy contrary to the rights of all; for whoever violates international law 
...violates it not only to the detriment of the person directly affected, but against all civilized States.

His conclusion is that under these circumstances collective intervention is 'obligatory'. 50

Bluntschli of Heidelberg University asserted that ' $[\mathrm{t}]$ he civilized nations in particular are called upon to develop the sentiment of the common laws of humanity' ${ }^{51}$ and that '[o]ne is authorized to intervene to ensure respect for the individual rights recognized as necessary ... an oppressed minority could ... provoke foreign intervention, not in the name of the state, but in the name of international law, ${ }^{52}$

\section{1-90: from Arntz and Martens to Carnazza Amari and Renault}

In the 1870 s and 1880 os many authorities advocated a legal right of humanitarian intervention, with a majority in favour, thirteen against ten, and if we add those from the previous period who were still active, the numbers are twenty-two to thirteen publicists (see table 4.1).

In the 1870 A Arntz set the pace with the following oft-quoted passage: ${ }^{53}$

When a government, although acting within the limits of its sovereign rights, violates the rights of humanity ... by an excess of injustice and cruelty, which deeply wounds our mores and civilization, the right of intervention is legitimate. For however worthy of respect may be the rights of sovereignty and the independence of States, there is something even more worthy of respect, and this is the law of humanity, or of human society, which must not be outraged.

Arntz specified that intervention in the name of humanity should be sanctioned by the greater number of civilized states, which should arrive at a collective decision, for only in this manner could intervention be reconciled with state independence. ${ }^{54}$

Rolin-Jaequemyns concurred with Arntz, and asked 'what would happen if in the place of a despotic monarch who is an outrage to the law of humanity, a victorious faction acts, in the name of a republic or a democracy, with analogous excess ... [embarks on] a civil war of extermination, massacring the prisoners and hostages and threatening to plunge again into barbary all the parts of the country that have not already become a desert'? ${ }^{55}$ Elsewhere he made the following pertinent point: for 'a State to lay claim to the principle of non-intervention it should be a State worthy of its name and a viable one. ${ }^{56}$

F. F. Martens, the major Russian jurist, referred in 1877, apropos of the Russian intervention in the Balkans (see chapter 9), to the 'interests of humanity' as a reason for intervention, in order to safeguard the interests recognized as worthy of sympathy by all the civilized nations', namely 'the life and honour of Christians'. ${ }^{57}$ A few years later he elaborated the point thus: ${ }^{58}$ 
In the relations of civilized peoples with the non-civilized ... the intervention by civilized states is in principle legitimate, in the case of a Christian population of those countries being exposed to barbaric persecutions or massacres. In this particular case intervention is justified by common religious interests and considerations of philanthropy.

This view regarding non-civilized states had first appeared in 1874 in a study in Russian by Leonid Komarovskiy, Martens's colleague at the University of Moscow, who was a student of Bluntschli and a frequent writer in the Revue. ${ }^{59}$

Those supportive of humanitarian intervention during this decade included Sheldon Amos, ${ }^{60}$ Professor of Jurisprudence at University College London, and the British judge Sir Edward Shepherd Creasy. ${ }^{61}$ Those decidedly against included the Catania professor and Italian politician Giuseppe Carnazza Amari, the French international lawyers Henri Bonfils ${ }^{62}$ and Louis Renault and the Luxembourgian French sociologist Théophile Funck-Brentano, together with the French historian Albert Sorel, ${ }^{63}$ Professor of Diplomatic History and co-founder of the École libre des sciences politiques.

As forcefully put by Giuseppe Carnazza Amari, Fiore's main rival in the Italian school on this question, a champion of non-intervention absolue: ${ }^{64}$

No case exists where a foreign sovereignty has the right to substitute national sovereignty; consequently intervention is never possible, neither as a rule nor as an exception.... All coercive influence from abroad constitutes a violent intrusion of one's domain, a supreme tyranny of the powerful against the weak, the usurpation and the rapine of the sovereign powers on which we have no right, an exercise of illegitimate power, a servitude imposed by the oppressor on the oppressed.

As for civil wars, he maintained that 'whatever the good intention may be of the one who wants to intervene, he lacks the right, for he has no sovereign authority over other nations ... the man with the best of intentions in the world cannot reconcile by force another family which leads a life of hate and troubles' ${ }^{65}$ Yet he allowed for three exceptions, which he did not regard as interventions and contraventions of non-intervention: assistance to a people who cannot on their own get rid of foreign domination; aid to a people who want to separate from a people with whom they have been forcefully united; and aid to a people to deliver themselves from foreign intervention and its results. ${ }^{66}$

Louis Renault of the University of Paris, the doyen of French international lawyers in the last two decades of nineteenth century, was equally averse to the idea of humanitarian intervention. As he tersely put it (in 1879): 'Very often the nations called civilized have abused their power with regard to the so-called barbarian peoples, having declared unjustified wars and having violated the most elementary rules of international law' ${ }^{67}$ Referring to Bluntschli's view on 
humanitarian intervention he notes that 'this may happen, but I think that it is not desirable, for the slope will be slippery' ${ }^{68}$

In the period 1880-90, those supporting humanitarian intervention include the British William Edward Hall and James Lorimer, ${ }^{69}$ the French diplomat Édouard Engelhardt, ${ }^{70}$ the Swiss Joseph Hornung ${ }^{71}$ and the Greek Michel Kebedgy, of the University of Berne. ${ }^{72}$

Hall at the start of the 188 os was circumspect in his widely read treatise of 1880 (with eight editions up to 1924), ${ }^{73}$ putting commentators at a loss where to place him in the debate. ${ }^{74}$ According to Hall, '[t] yrannical conduct of a government towards its subjects, massacres and brutality in a civil war, or religious persecution, are acts which have nothing to do directly or indirectly with such [inter-state] relations' ${ }^{75}$ But he concluded that intervention 'for the reason or upon the pretexts of cruelty, or oppression, or the horrors of civil war ... could only be excused in rare and extreme cases in consideration of the unquestionably extraordinary character of the facts causing them, and of the evident purity of the motives and conduct of the intervening state' ${ }^{76}$

The 188 os also saw one of the clearest presentations of the arguments against humanitarian intervention, by the French jurist Paul Louis Pradier-Fodéré, one-time Professor of International Law at the University of Lima and author of a multivolume treatise on international law, who referred to the views of Arntz, Rolin-Jaequemyns, Woolsey and Fiore in support of intervening for humanitarian reasons, but concluded that 'it is impossible to accept such a doctrine, ${ }^{77}$ for: ${ }^{78}$

A nation could still be in such a backward stage as to accommodate absolutism, to voluntarily suffer despotism; on the basis of what right can foreign Powers claim that they can impose liberty? A nation, even a backward one, is the only one competent to regulate its political, civil and religious organization; it is free to adopt its form on the basis of its customs and ideas; foreign peoples are not entitled to impose them.

For Pradier-Fodéré, humanitarian intervention 'is illegitimate for it constitutes an infringement upon the independence of States... The acts of inhumanity, however condemnable they may be, as long as they do not affect or threaten the rights of other States, do not provide the latter with a basis for lawful intervention, as no State can stand up in judgment of the conduct of others' ${ }^{79}$

\section{1-1918: from Lawrence and Rivier to Westlake, Oppenheim and Nys}

In the 1890 and until the end of the First World War, the advocates total eighteen and the opponents thirteen, and if we add those from the previous period who were still active, the numbers are nearly equal, twenty-six advocates and twentyfour opposed (see table 4.1). 
During the 1890 s the jurists supportive of humanitarian intervention include the British Thomas Joseph Lawrence, the Swiss Alphonse Rivier, the French Antoine Pillet, ${ }^{80}$ Louis Le Fur ${ }^{81}$ and Albert de Lapradelle, ${ }^{82}$ and the Americans Amos S. Hershey ${ }^{83}$ and Theodore S. Woolsey. ${ }^{84}$ Those against in the 1890 os include the French Frantz Despagnet, the Germans Franz von Liszt ${ }^{85}$ and Adolphe de Floeckher ${ }^{86}$ and the British Thomas Alfred Walker. ${ }^{87}$

In 1895 Lawrence of Oxford University put it thus: ${ }^{88}$

Should the cruelty be so long continued and so revolting that the best instincts of human nature are outraged by it, and should an opportunity arise for bringing it to an end and removing its cause without adding fuel to the flame of the contest, there is nothing in the law of nations which will condemn as a wrong-doer the state which steps forward and undertakes the necessary intervention. Each case must be judged on its own merits ... I have no right to enter my neighbor's garden without his consent; but if I saw a child of his robbed and ill-treated in it by a tramp, I should throw ceremony to the wind and rush to the rescue without waiting to ask for permission.

Rivier, a year later, referred approvingly to the views of Arntz and RolinJaequemyns and asserted that ' $[\mathrm{t}]$ he law of human society ... represented by the Society of nations is superior to the law of a nation on its own. When a State violates the law of humanity, it is not for one state to intervene, on its own, and without a mandate. But States as a whole, representing human society, which is injured ... have the right to intervene as in the case of one State on its own which intervenes when its proper right of preservation is injured' ${ }^{89}$

Among opponents, Despagnet of the University of Bordeaux argued that intervention against a government 'which in its exercise of internal sovereignty violates the laws of humanity ... cannot be accepted, as it gives rise to abuse and, under the pretext of safeguarding the interests of populations, it completely ruins the respect of State sovereignty; a government could, for example, not permit slavery or halt the traffic of slaves in all the domains that fall under its own authority, but it cannot impose the suppression [of slavery] to other States in their territory'. ${ }^{90}$

In the early twentieth century and until the end of the 'Great War', supporters of humanitarian intervention include John Westlake, Lassa Oppenheim, the French Alexandre Mérignhac ${ }^{91}$ and Antoine Rougier, the Italian Arrigo Cavaglieri, ${ }^{92}$ and the Americans William Ezra Lingelbach, ${ }^{93}$ Edwin Borchard ${ }^{94}$ and Henry Green Hodges. ${ }^{95}$ Those against include the British Thomas Erskine Holland ${ }^{96}$ and Frederick Edwin Smith, ${ }^{97}$ the Belgian Ernest Nys, the German Karl von Gareis, ${ }^{98}$ and the Americans George Grafton Wilson and Charles Cheney Hyde. ${ }^{99}$

Westlake referred to anarchy and misrule as grounds for intervention ${ }^{100}$ and stated ' $\mathrm{i}$ ] $\mathrm{t}$ is idle to argue in such a case that the duty of neighbouring peoples is to look on quietly. Laws are made for men and not for creatures of the imagination, and they must not create or tolerate for them situations which are beyond the endurance'. ${ }^{101}$ 
Oppenheim was more circumspect in his monumental 1905 treatise, contending that ' $[\mathrm{m}]$ any jurists maintain that intervention is ... admissible, or even has a basis of right, when exercised in the interest of humanity for the purpose of stopping religious persecution and endless cruelties in time of peace and war' and he referred to intervention in the Greek case. ${ }^{102}$ And added ' $[\mathrm{b}]$ ut whether there is really a rule of the Law of Nations which admits such intervention may well be doubted ... and it may perhaps be said that in time the Law of Nations will recognise the rule that interventions in the interest of humanity are admissible, provided they are exercised in the form of collective intervention of the Powers'. ${ }^{103}$

Rougier argued that collective humanitarian intervention was preferable to individual intervention for it is more able to establish 'disinterestedness and greater authority' ${ }^{104} \mathrm{He}$ was the first jurist to present a list of criteria for humanitarian intervention, including 'a violation of the law of humanity and not merely a violation of positive national law' ${ }^{105}$ and 'exceptionally grave cases, as when the life of an entire population is menaced, when the barbaric acts are often repeated, when their character is particularly horrible that it violently shocks the universal consciousness'. ${ }^{106}$ He also refers to considerations of opportunity, appeals by the victims and favourable conditions for intervening. ${ }^{107}$

On the side of the opponents, worth referring to are the points raised by Nys and Wilson. Nys argued that independence for States is like liberty for the individual' ${ }^{\prime 108}$ and referred approvingly to the views of Renault and PradierFodéré against intervention. ${ }^{109}$ As for the admixture of the European powers in the Eastern Question, he maintained that 'it cannot be invoked to justify the doctrine of intervention', for it was something else: 'the establishment of a protectorate regarding the Christian nations under the sultan'. ${ }^{110}$

Wilson, Professor of International Law at Harvard University and at the Fletcher School of Law and Diplomacy, pointed out that '[f] or a state to set itself up as a judge of the actions of another state and to assume that it has the right to extend its powers to settling and regulating affairs of morals, religion, and the relations of public authority to the subjects in another state, on the ground of maintaining the rights of mankind as a whole, is to take a ground which the conduct of any modern state, even the most civilized, would hardly warrant'. ${ }^{11}$

\section{9-39: from Stowell and Higgins to Lauterpacht and Politis}

Surprisingly, during the inter-war period, at a time when no humanitarian intervention took place, the overwhelming majority of advocates who addressed the question for the first time is in support, at eighteen, as opposed to only six opponents, and if we add those from the previous period who were still active, the advocates total thirty-three as opposed to fourteen against (see table 4.1).

Supporters include the Polish-British Hersch Lauterpacht, the French Paul Fauchille ${ }^{112}$ and Georges Scelle, ${ }^{113}$ the Americans Ellery Stowell, Charles 
Fenwick ${ }^{114}$ and Pitman Potter, ${ }^{115}$ the Greeks Nicolas Politis ${ }^{116}$ and Stélio Séfériadès ${ }^{117}$ (father of Nobel Laureate poet George Seferis), and the Russians André Mandelstam ${ }^{118}$ and Michel Taube. ${ }^{119}$ Those against include the British Alexander Pearce Higgins, Percy Winfield ${ }^{120}$ and James Leslie Brierly, ${ }^{121}$ the French Robert Redslob ${ }^{122}$ and the German Karl Strupp.

We will start with the opponents this time round. Strupp, of Frankfurt University and later Istanbul University, discussed the views of Cavaglieri in support of collective humanitarian intervention ${ }^{123}$ and concluded that it is unacceptable and dangerous, and given the fact that 'no one can say how many States suffice to constitute a collectivity, we are led to practically authorize the great Powers to interfere in the affairs of smaller States.' ${ }^{24}$

According to Higgins, Whewell Professor in Cambridge, interventions in instances of social upheavals and civil wars 'constitute a grave danger to international harmony because they offer an opportunity to an unprincipled state to take undue advantage of the internal weakness or maladministration of such a state to increase its own power'. ${ }^{125}$ Thus it may acquire 'a de facto protectorate while protesting that its intervention is in the interests of humanity.' ${ }^{126}$

Moving on to the advocates, Stowell, of Columbia University, advocated humanitarian intervention, for no state 'may persist in conduct which is considered to violate the universally recognized principles of decency and humanity'. ${ }^{127} \mathrm{He}$ accepted that 'recourse to intervention on the ground of humanity may at times offer a cloak for interference and aggression,, ${ }^{128}$ but maintained that 'a deliberate violation of that minimum of security and justice to which every individual in a civilized community is entitled' made it 'the right and duty of other states to intervene'. ${ }^{129}$

Lauterpacht, one of the greatest international lawyers of the twentieth century, then in his thirties, who succeeded Higgins as Whewell Professor, had the following to say on the matter: ${ }^{130}$

The sovereign and independent State receives from international law absolute autonomy as regards the treatment of its inhabitants... But this exclusive right could be abused, in which case it ceases to be a right and the competence of international law to protect the individual reasserts all its force ... humanitarian intervention is both a juridical as well a political principle of international society.

Politis, one of the most innovative international jurists of the inter-war period and a key figure in the League of Nations, ${ }^{131}$ Professor at the University of Paris and later Greek Foreign Minister, made the following important point in his book on international morality, written just before the Second World War and published posthumously: ${ }^{132}$

Every people has the right to organise itself as it wants ... without other countries being in the position to oppose or to intervene in what are internal affairs... But ... such a right will merit due respect on the principle that it makes reasonable use 
of it. If, on the contrary, it gives ground to abuses of power ... and, in general, if the prescriptions of international morality and of international law are downtrodden, other countries are entitled to intervene; they could put into play the rules of international responsibility.

\section{Overall assessment}

As we have seen, most of the issues for and against humanitarian intervention raised today were developed in the period $1830-1939:^{133}$ the moral drive to do something for the oppressed in instances where the moral consciousness of humankind is shocked, the abuse factor, a level of disinterestedness, the need to maintain the principle of sovereignty and independence, the assuredness of a successful outcome stopping the bloodshed and so on.

It has been suggested that the Anglo-Americans were more supportive than the continental schools. ${ }^{134}$ In fact there is an even split within the British and French schools of thought. Most US jurists supported intervention on legal or moral grounds, though a substantial minority were against. Russian publicists (apparently with the Ottoman Empire in mind) as well as those from the small states of Europe, such as Switzerland, Belgium and Greece, were all, with no exception, advocates of humanitarian intervention. The Italian school tilts more towards non-intervention, though with the proviso of support for liberation movements and counter-intervention. The only group that was for the most part against is the German school, which may perhaps be attributed to the fact that Prussia, Germany and Austria-Hungary refrained from intervening militarily in humanitarian plights or in internal wars.

Until 1914 all publicists, with very few exceptions, adhered to the civilizedbarbarian distinction (see chapter 3), but most advocates avoided any distinction as to its application, which implies that they considered, as a matter of principle, that intervention for reasons of humanity is applicable to all, irrespective of degree of civilization.

Some of the supporters of humanitarian intervention were explicit in this regard. Hornung posited that such intervention had to be raised 'above considerations of religion or race' and become 'truly humanitarian in character.'. 135 It should apply if need be 'against the Christian, in favour of the Muslim, the Buddhist or the pagan'. ${ }^{136}$

According to Fauchille, humanitarian intervention is practised 'vis-à-vis civilized States as well: after all is not the violation of the right of humanity more grave when it emanates from a civilised State?'137

Kebedgy referred to the difficulty of distinguishing between civilized and non-civilized states, pointing out that atrocities could be committed by a state called civilized; if its actions indeed made it barbarous, it would lose 'all title to respect for its independence'. 138 
But some publicists supportive of humanitarian intervention claim, as we have seen, that it is applicable only to 'civilized states' against 'non-civilized states'. They include Martens, Komarovskiy, Lorimer, partly Bluntschli ${ }^{139}$ and, in the early twentieth century, Edwin DeWitt Dickinson, ${ }^{140}$ Phillimore regarding the Muslim states, and Engelhardt and Rolin-Jaequemyns regarding the Ottoman Empire per se. ${ }^{141}$ According to Phillimore, 'the right of Christian Intervention on religious grounds in a Mohammedan State rests upon an obviously stronger foundation'. ${ }^{142}$ But he adds, to his credit, that '[ $\left.\mathrm{t}\right]$ he converse of this, viz., Mohammedan Intervention with Christian States, has, it is believed, never yet arisen in practice, but it would be subject on principle to the same law.' ${ }^{143}$

Ironically, the double standards of humanitarian intervention and the singling out of non-Christian states for intervention were criticized by opponents of the concept of humanitarian intervention, who presented their supportive peers as unprincipled. They include Pradier-Fodéré, ${ }^{144}$ Funck-Brentano and Sorel, ${ }^{145}$ Bonfils, ${ }^{146}$ Renault, ${ }^{147}$ Despagnet, Floeckher ${ }^{148}$ and Winfield. ${ }^{149}$

Despagnet, for instance, referred to 'an alleged right of civilization that permits European peoples in particular to act against barbarian governments so as to impose upon them more ethical and humane institutions, ${ }^{150}$ adding that it was open to abuse 'under the cover, often hypocritical, of a disinterested civilizing mission'. ${ }^{151}$

Now we come to the fundamental question whether armed humanitarian intervention had become part of customary international law at the time, the majority view of legal authors from 1920 until today. ${ }^{152}$ This overall trend is accepted even in some of today's polemics on the concept. ${ }^{153}$ Clearly, a majority (more than three-quarters) were in favour of humanitarian intervention, be it on legal or moral grounds. However, in order to claim that a legal right did exist, one has to wrongly lump those advocating a legal right with those invoking moral or political grounds, ${ }^{154}$ even though the latter explicitly deny such a legal right. It would be more accurate to say that from 1830 until 1939 the views were 'divided'; ${ }^{155}$ it was 'debatable ${ }^{\prime 156}$ or 'doubtful' ${ }^{157}$ whether such a right existed in positive international law.

But when it comes to humanitarian intervention as conceived in the pre-UN Charter period, which also included peremptory demands and forms of dictatorial interference short of the actual use of armed force, ${ }^{158}$ it appears that humanitarian intervention lato sensu was part of customary international law from the $1860 \mathrm{os}$ or 1870 s onwards. In itself this is a striking finding, for the international law of human rights was yet to come, with the exception of the minority treaties regime in the peace treaties signed in Paris (1919-20) and Lausanne (1923), which hardly gave ground for intervention (their whole philosophy was minority rights in exchange for loyalty on the part of the minorities ${ }^{159}$ ).

We will conclude by reverting to the double-standard aspect. From an international law perspective, one view is that of Komarovskiy, Martens and others, 
that such a right exists only with regard to civilized states towards barbarous states if Christians are harshly treated. Another line is to regard it as a lex specialis in the relations of European states with the Ottoman Empire or China, as advocated by Bluntschli, ${ }^{160}$ Rolin-Jaequemyns, ${ }^{161}$ Westlake, ${ }^{162} \mathrm{Nys}^{163}$ and Rougier. ${ }^{164} \mathrm{~A}$ third option is to regard the possibility of humanitarian intervention as a 'special custom' applicable only in the relations of Europe with the Ottoman Empire. ${ }^{165}$ By today's criteria this approach is problematic, for special (or regional) customs have to be applied reciprocally and not for the benefit of one party at the expense of the other. Clearly, none of these options would carry the day in current international law, but international law as conceived in the long nineteenth century was, for better or worse, the law of the European states (and those of European extraction), those with the 'standard of civilization' to boot, hence the double standards that come out naturally from this perspective, however antiquated. If we draw such a conclusion we also avoid the danger of retrospective thinking.

\section{Notes}

1 M. Koskenniemi, From Apology to Utopia: The Structure of International Legal Argument (Cambridge: Cambridge University Press, 2005), 122-3. For the state of play of international law in France, Germany and Britain, see M. Koskenniemi, The Gentle Civilizer of Nations: The Rise and Fall of International Law 1870-1960 (Cambridge: Cambridge University Press, 2002), 30-3.

2 C. Sylvest, 'The Foundations of Victorian International Law', in Duncan Bell (ed.), Victorian Visions of Global Order: Empire and International Relations in NineteenthCentury Political Thought (Cambridge: Cambridge University Press, 2007), 48; C. Sylvest, British Liberal Internationalism, 1830-1930: Making Progress? (Manchester: Manchester University Press, 2009), 63-6, 69.

3 Sylvest, British Liberal Internationalism, 48.

4 J. Austin, Lectures in Jurisprudence or the Philosophy of Positive Law (London: John Murray, 1885, 5th edition) [1861], 182 (original emphasis).

5 Ibid., 184.

6 Koskenniemi, The Gentle Civilizer of Nations, 12-14.

7 Ibid., 40-1; C. Sylvest, 'International Law in Nineteenth Century Britain', British Year Book of International Law, 75 (2004), 46.

8 'To promote the progress of international law, striving to become the organ of the legal conscience of the civilized world'. Quoted in Koskenniemi, The Gentle Civilizer of Nations, 41.

9 Ibid., 42. Fiore used similar language. See chapter 3.

10 Koskenniemi, The Gentle Civilizer of Nations, 41.

11 See on the link between the discipline of history and nationalism, J. Hutchinson, Modern Nationalism (London: Harper Collins, 1994), 3.

12 W. G. Grewe, The Epochs of International Law (Berlin: Walter de Gruyter, 200o, translated and revised by M. Byers) [1984], 493.

13 A. C. Arend, and R. J. Beck, International Law and the Use of Force (London: Routledge, 1993), 17. 
14 O. Ramsbotham and T. Woodhouse, Humanitarian Intervention: A Reconceptualization (Cambridge: Polity Press, 1996), 36.

15 S. Chesterman, Just War or Just Peace? Humanitarian Intervention and International Law (Oxford: Oxford University Press, 2001), 8.

16 M. Barnett, Empire of Humanity: A History of Humanitarianism (Ithaca: Cornell University Press, 2011), 76-94.

17 D. Schindler, 'International Humanitarian Law: Its Remarkable Development and Its Persistent Violation', Journal of the History of International Law, 5 (2003), 166.

18 H. Strebel, 'Martens's Clause', Encyclopedia of Public International Law, Max Planck Institute for Comparative Public Law and International Law (Amsterdam: Elsevier, 1997), 326; E. Schwelb, 'Crimes Against Humanity', British Year Book of International Law, 23 (1946), 178-82; Grewe, The Epochs of International Law, 494-5; T. Meron, The Humanization of International Law (Leiden: Martinus Nijhoff, 2006), 16-18. On the contribution of Russians jurists in this regard (of Martens and others) see E. Myles, "Humanity", "Civilization" and the "International Community" in the Late Imperial Russian Mirror: Three Ideas “Topical for our Days”, Journal of the History of International Law, 4 (2002), 316-19.

19 A. Rougier, 'La théorie de l'intervention d'humanité', Revue générale de droit international public, 17 (1910), 473-8, 499-526; E. C. Stowell, Intervention in International Law (Washington, DC: John Byrne, 1921), 51-62; M. Ganji, International Protection of Human Rights (Geneva: Librairie E. Droz, 1962), 37-8; J.-P. L. Fonteyne, 'The Customary International Law Doctrine of Humanitarian Intervention: Its Current Validity Under the U.N. Charter', California Western International Law Journal, 4 (1973-74), 235; F. K. Abiew, The Evolution of the Doctrine and Practice of Humanitarian Intervention (The Hague: Kluwer Law International, 1999), 42-3; Grewe, The Epochs of International Law, 493.

20 We hardly claim to have discovered all the publicists involved in the debate. Our main omissions are those writing in German, Italian or Spanish and in lesser known European languages, whose works were not translated into English or French.

21 The rest of this chapter is based in part on an earlier version, for which ninety-four publicists were identified. See A. Heraclides, 'Humanitarian Intervention in International Law 1830-1939: The Debate', Journal of the History of International Law, 16 (2014), $26-62$.

22 See Rougier, 'La théorie de l'intervention d'humanité', 490 n.3; A. Mandelstam, 'La protection des minorités', Recueil des cours de l'Académie de droit international, 1 (1923), 389-90.

23 Arntz's letter in G. Rolin-Jaequemyns, 'Note sur la théorie du droit d'intervention, à propos d'une lettre de M. le professeur Arntz', Revue de droit international et de législation comparée, 8 (1876), 673-5.

$24 \mathrm{H}$. Wheaton, Elements of International Law: With a Sketch of the History of the Science (Philadelphia: Carey, Lea and Blanchard, 1836), 91 (emphasis added). See also H. Wheaton, Elements of International Law (Boston: Little, Brown and Co., 1866, 8th edition, edited by R.H. Dana) [1836], 113 .

25 In G. Carnazza Amari, 'Nouvel exposé du principe de non-intervention', Revue de droit international et de législation comparée, 5 (1873), 376-7; and in Stowell, Intervention in International Law, 524 .

26 N. W. Senior, 'Art.I-1. Histoire du Progrès du Droit des Gens depuis la Paix de Westphalie jusqu'au Congrès de Vienne. Par Henry Wheaton', Edinburgh Review, 77:156 (1843), 365.

27 Ibid., 334. 
28 Cited and commented upon in Stowell, Intervention in International Law, 494.

29 A. W. Heffter Le droit international de l'Europe (Berlin: H. W. Muller and Paris: A. Cotillon et Cie, 1883, 4th French edition, translated from the German by J. Bergson) [1844], 111.

30 Ibid., 113-14.

31 Quoted and translated in Stowell, Intervention in International Law, 525.

32 R. Phillimore, Commentaries upon International Law (London: Butterworth, 1879, 3rd edition) [1854], vol. I, 568 (original emphasis).

33 Ibid., 568-9.

34 Ibid., 622-3.

35 T. D. Woolsey, Introduction to the Study of International Law (London: Sampson Low, Marston, Searle and Rivington, 1879, 5th edition revised and enlarged) [1860], 44 .

36 Ibid., 44.

37 Quoted and translated in Stowell, Intervention in International Law, 472; and Rougier, 'La théorie de l'intervention d'humanité', 490 n.2 (from Berner's book, Deutsche Staatswörterbuch, Leipzig, 1860).

38 Count Mamiani, Rights of Nations, or the New Law of European States Applied to the Affairs of Italy (London: W. Jeffs, 1860, translated from the Italian by R. Acton) [1859], 177.

39 Ibid., 194.

40 Ibid., 140-1.

41 Ibid., 197.

42 M. Bernard, On the Principle of Non-Intervention: A Lecture Delivered in the Hall of All Souls College, December MDCCCLX (Oxford: J. H. and J. Parker, 1860), 9, 18-20, 23.

43 Ibid., 21-2.

44 Ibid., 33-4.

45 H. W. Halleck, Halleck's International Law or Rules Regulating the Intercourse of States in Peace and War (London: Kegan Paul, Trench, Trübner, 1893, 3rd edition by S. Baker) [1861], vol. I, 101, 511.

46 Harcourt, writing under the pen-name Historicus, in Letters by Historicus on Some Questions of International Law. Reprinted from 'The Times' with Considerable Additions (London: Macmillan, 1863), 14.

47 Ibid., 50.

48 P. Fiore, Nouveau droit internationale public suivant les besoins de la civilization moderne (Paris: A. Durant et Pedone-Lauriel, 1885, 2nd edition, translated from the Italian and annotated by C. Antoine) [1865], vol. I, 502.

49 Ibid., 524-5.

50 P. Fiore, International Law Codified and Its Legal Sanction or the Legal Organization of the Society of States (New York: Baker, Voorhis and Company, 1918, translation from the 5 th Italian edition with an introduction by E. M. Borchard), 269.

51 J. C. Bluntschli, Le droit international codifié (Paris: Librairie de Guillaumin et Cie, 1874, 2nd French edition, translated from the German by M. C. Lardy) [1868], 55, para. 5.

52 Ibid., 272, para. 478.

53 Arntz quoted in Rolin-Jaequemyns, 'Note sur la théorie du droit d'intervention', 675.

54 Ibid., 675.

55 Ibid., 676.

56 G. Rolin-Jaequemyns, 'Le droit international et la phase actuelle de la question d'Orient', Revue de droit international et de législation comparée, 8 (1876), 396.

57 F. Martens, 'Étude historique sur la politique Russe dans la question d'Orient', Revue de droit international et de législation comparée, 9 (1877), 49. 
58 F. Martens, Sovremennoe Mezhdunarodnoe Pravo Tsivilizovannykh Narodov (St Petersburg: Tipografiya A. Benke, 1904, 5th edition) [1883], vol. I, 310.

59 L. Komarovskiy, Nachalo nevmeshatel'stva (Moscow: Universitetskaja Tipografiya, 1874), 79-80. Martens refers to him as well as to Bluntschli and Phillimore, to buttress his view.

60 S. Amos (from Lecturers on International Law, 1874, 39-41) in Chesterman, Just War or Just Peace?, 37; S. Amos, Political and Legal Remedies for War (London: Cassel, Petter, Galpin, 1880), 79.

61 E. S. Creasy, First Platform of International Law (London: John van Voorst, 1876), 303-4.

62 H. Bonfils, Manuel de droit international public (droit des gens) (Paris: Librairie nouvelle de droit et de jurisprudence, 1905, 4th edition by Paul Fauchille) [1877], 155, para. 298.

63 T. Funck-Brentano and A. Sorel, Précis du droit des gens (Paris: Librairie Plon, 1887, 2nd edition) [1877], 215-16, 221, 223.

64 Carnazza Amari, 'Nouvel exposé du principe de non-intervention', 370.

65 Ibid., 375.

66 Ibid., 552-9.

67 L. Renault, Introduction à l'étude du droit international (Paris: L. Larose, 1879), 21-2.

68 Ibid., 23.

69 J. Lorimer, The Institutes of the Law of Nations: A Treatise of the Jural Relations of Separate Political Communities (Edinburgh: William Blackwood and Sons, 1883, 1884), vol. I, 101-2; and vol. II, 51, 54 .

70 É. Engelhardt, Le droit d'intervention et la Turquie. Étude historique (Paris: A. Cotillon et Cie, 1880), 10-11.

71 J.Hornung, 'Civilisés et barbares', Revue de droit international et de législation comparée, 17 (1885), 13-14.

72 According to Stowell, in Stowell, Intervention in International Law, 65 n.14, based on M. Kebedgy, De l'intervention: théorie générale et étude spécial de la question d'Orient (Paris: A. Giard, 1890).

73 W. E. Hall, A Treatise of International Law (Oxford: Clarendon Press, 1895, 4th edition) [1880]. The 8th edition, of 1924 , was edited by A. P. Higgins.

74 See for instance the bafflement of Stowell in Stowell, Intervention in International Law, 6o-1 n.13.

75 Hall, A Treatise of International Law, 302-3.

76 Ibid., 304.

77 P. L. Pradier-Fodéré, Traité de droit international public européen et américain, suivant le progrès de la science et de la pratique contemporaines (Paris: A. Durand et Pedone-Lauriel, 1885), vol. I, 593-4.

78 Ibid., 594-5.

79 Ibid., 663.

80 A. Pillet, 'Le droit international public', Revue générale de droit international public, 1 (1894), 13, 16.

81 L. Le Fur, 'Chronique des faits internationaux', Revue générale de droit international public, 5 (1898), 664-5.

82 A. de Lapradelle, 'Chronique sur les affaires de Cuba', Revue de droit publique et de science politique en France et à l'étranger, 1 (1900), 75.

83 A. S. Hershey, 'Intervention and the Recognition of Cuban Independence', Annals of the American Academy of Political and Social Science, 11 (1898), 58, 77-80; A. S. Hershey, 'The Calvo and Drago Doctrines', American Journal of International Law, 1:1 (1907), 41-2. 
84 T. S. Woolsey, American Foreign Policy (New York: Century, 1898), 75-6.

85 According to P. Malanczuk, Humanitarian Intervention and the Legitimacy of the Use of Force (Amsterdam: Het Spinhuis, 1993), 10.

86 A. de Floeckher, De l'intervention en droit international (Paris: A. Pedone, 1896), 5, 36-8; A. de Floeckher, 'Les conséquences del'intervention', Revue générale de droit international public, 3 (1896), 329-33.

87 T. A. Walker, The Science of International Law (London: C. J. Clay and Sons, 1893), 151-2; T. A. Walker, A Manual of Public International Law (Cambridge: Cambridge University Press, 1895), 22.

88 T.J. Lawrence, The Principles of International Law (Boston: D. C. Heath, 1905, 3rd edition, revised) [1895], 120.

89 A. Rivier, Principes $d u$ droit des gens (Paris: Librairie nouvelle de droit et de jurisprudence, 1896), 403 .

90 F. Despagnet, Cours de droit international public (Paris: L. Larose, 1894), 189.

91 A. Mérignhac, Traité de droit public international (Paris: Librairie générale de droit et de jurisprudence, 1905), part i, 298-9.

92 A. Cavaglieri, L'intervento nella sua definizione guiridica (Bologna: Luigi Betrami, 1913), 106-9.

93 W. E. Lingelbach, 'The Doctrine and Practice of Intervention in Europe', Annals of the Academy of Political and Social Science, 16 (1900), 17, 20, 32.

94 E. M. Borchard, 'Basic Elements of Diplomatic Protection of Citizens Abroad', American Journal of International Law, 7:3 (1913), 507.

95 H. G. Hodges, The Doctrine of Intervention (Princeton: Banner Press, 1915), 87-8, 91.

96 T. E. Holland, Lectures on International Law (London: Sweet and Maxwell, 1933, edited by Thomas Alfred Walker and Wyndham Legh Walker), 105, 108.

97 F. E. Smith, International Law (London: J. M. Dent and Sons, 1911, 4th edition, revised and enlarged by J. Wylie) [1900], 63-4.

98 According to Fonteyne, 'The Customary International Law Doctrine of Humanitarian Intervention', 217 n.42, based on K. von Gareis, Institutionen des Völkerrechts (2nd edition, 1901).

99 C. C. Hyde, 'Intervention in Theory and in Practice', Illinois Law Review, 6:1 (1911), 6-7.

100 J. Westlake, International Law, Part I: Peace (Cambridge: Cambridge University Press, 1904), 305-6.

101 Ibid., 306-7.

102 L. Oppenheim, International Law: A Treatise (London: Longmans, Green, 5th edition, edited by H. Lauterpacht, 1937) [1905], vol. I, 255, para. 137. Lauterpacht notes that he has left para. 137 unaltered from the 1905 edition.

103 Ibid., 255, para. 137 (original emphasis).

104 Rougier, 'La théorie de l'intervention d'humanité', 502.

105 Ibid., 515.

106 Ibid., 523-4.

107 Ibid., 523-5.

108 E. Nys, Le droit international: les principles, les théories, les faits (Brussels: M. Weissenbruch, 1912, new edition) [1906], vol. II, 223.

109 Ibid., 230-1.

110 Ibid., 232.

111 G. G. Wilson, International Law (New York: Silver, Burdett, 1922, 8th edition) [1901], 91. 
112 P. Fauchille, Traité de droit international public (Paris: Rousseau et Cie, 8th updated and completely rewritten edition of Bonfils's Manuel de droit international public (droit des gens), 1926) [1877], vol. I, part i, 570-1.

113 According to Hubert Thierry, Scelle introduced 'a sort of duty of interference' (devoir d' ingérence). See H. Thierry, 'The Thought of Georges Scelle', European Journal of International Law, 1 (1990), 196.

114 C. G. Fenwick, International Law (London: George Allen and Unwin, 1924), 154-5.

115 P. B. Potter, 'L'intervention en droit international moderne', Recueil des cours del'Académie de droit international, 32 (1930), 653.

116 N. Politis, 'Le problème des limitations de la souveraineté et la théorie de l'abus des droits dans les rapports internationaux', Recueil des cours d l'Académie de droit international, 9 (1924), 6; N. Politis, La morale international (Paris: Bibliothèque Brentano's, 1944), 144 .

117 S. Séfériadès, 'Principes généraux du droit international de la paix', Recueil des cours de l'Académie de droit international, 34 (1930), 388-9.

118 Mandelstam, 'La protection des minorités', 391.

119 Le Baron Michel Taube, 'Études sur le dévelopement historique du droit international dans l'Europe orientale', Recueil des cours de l'Académie de droit international, 11 (1926), 492-3.

120 P. H. Winfield, 'The Grounds of Intervention in International Law', British Year Book of International Law, 5 (1924), 161-2.

121 J. L. Brierly, The Law of Nations: An Introduction to the International Law of Peace (Oxford: Clarendon Press, 1936, 2nd edition) [1928], 248-9.

122 R. Redslob, Traité de droit de gens (Paris: Librairie du Recueil Sirey, 1950), 23-4.

$123 \mathrm{~K}$. Strupp, 'Le règles générales du droit de la paix', Recueil des cours de l'Académie de droit international, 47 (1934), 519-20.

124 Ibid., 520.

125 A. P. Higgins, Studies in International Law and Relations (Cambridge: Cambridge University Press, 1928), 27.

126 Ibid., 27.

127 Stowell, Intervention in International Law, 51-2.

128 E. C. Stowell, 'Humanitarian Intervention', American Journal of International Law, 33:4 (1939), 734 .

129 Ibid., 734. See also E. C. Stowell, 'La théorie et la pratique de l'intervention', Recueil des cours de l'Académie de droit international, 40 (1932), 138-48.

130 H. Lauterpacht, 'Règles générales du droit de la paix', Recueil des cours de l'Académie de droit international, 62 (1937), 238.

131 For the contribution of Politis to international law, see Koskenniemi, The Gentle Civilizer of Nations, 305-9, 314. See also R. Holsti, 'In Memoriam: Nicolas Politis, 1872-1942', American Journal of International Law, 36:3 (1942), 475-9.

132 Politis, La morale international, 144.

133 This is accepted even by Simon Chesterman, a critic of humanitarian intervention in the nineteenth century. See Chesterman, Just War or Just Peace?, 42.

134 See e.g. Malanczuk, Humanitarian Intervention and the Legitimacy of the Use of Force, 10.

135 Hornung, 'Civilisés et barbares', 14.

136 Ibid., 13.

137 Fauchille, Traité de droit international public, vol. I, part i, 571.

138 Referred to in Stowell, Intervention in International Law, 65 n.14. 
139 According to Bonfils, in Bonfils, Manuel de droit international public, 169.

140 E. DeWitt Dickinson, The Equality of States in International Law (Cambridge: Harvard University Press, 1920), 262-3.

141 Engelhardt, Le droit d'intervention et la Turquie, 61; Rolin-Jaequemyns, 'Le droit international et la phase actuelle de la question d'Orient', 295-85.

142 Phillimore, Commentaries upon International Law, vol. I, 621.

143 Ibid., 624.

144 Pradier-Fodéré, Traité de droit international public européen et américain, 594-5.

145 Funck-Brentano and Sorel, Précis du droit des gens, 223.

146 Bonfils, Manuel de droit international public, 169.

147 Renault, Introduction à l'étude du droit international, 21-2.

148 Floeckher, De l'intervention en droit international, 38.

149 Winfield, 'The Grounds of Intervention in International Law', 161-2.

150 Despagnet, Cours de droit international public, 190 (original emphasis).

151 Ibid., 190.

152 Mandelstam, 'La protection des minorités', 391; Stowell, Intervention in International Law, 51-62; Fonteyne, 'The Customary International Law Doctrine of Humanitarian Intervention', 223; R. B. Lillich, 'Humanitarian Intervention: A Reply to Ian Brownlie and a Plea for Constructive Alternatives', in J. N. Moore (ed.), Law and Civil War in the Modern World (Baltimore: Johns Hopkins University Press, 1974), 232-5; T. E. Behuniak, 'The Law of Unilateral Humanitarian Intervention by Armed Force: A Legal Survey', Military Law Review, 79 (1978), 166; M. Bazyler, 'Reexamining the Doctrine of Humanitarian Intervention in Light of the Atrocities in Kampuchea and Ethiopia', Stanford Journal of International Law, 23 (1987), 572-4; B. M. Benjamin, 'Unilateral Humanitarian Intervention: Legalizing the Use of Force to Prevent Human Rights Atrocities', Fordham International Law Journal, 16 (1992-93), 126; U. Beyerlin, 'Humanitarian Intervention', in Encyclopedia of Public International Law, Max Planck Institute for Comparative Public Law and International Law (Amsterdam: Elsevier, 1995), vol. II, 927; Abiew, The Evolution of the Doctrine and Practice of Humanitarian Intervention, 33, 43; C. F. Amerasinghe, 'The Conundrum of Recourse to Force - To Protect Persons', International Organizations Law Review, 3 (2006), 11, 23-26, 38.

153 See e.g. I. Brownlie, International Law and the Use of Force by States (Oxford: Clarendon Press, 1963), 338. Contra see Malanczuk, Humanitarian Intervention and the Legitimacy of the Use of Force, 11; Chesterman, Just War or Just Peace?, 36, 43-4.

154 As rightly pointed out by Chesterman in Chesterman, Just War or Just Peace?, 36.

155 Malanczuk, Humanitarian Intervention and the Legitimacy of the Use of Force, 10.

156 Beyerlin, 'Humanitarian Intervention', 927.

157 Oppenheim, International Law, vol. I, 255. See also Ganji, International Protection of Human Rights, 43; Grewe, The Epochs of International Law, 494-5; Malanczuk, Humanitarian Intervention and the Legitimacy of the Use of Force, 11; G. Sulyok, 'Humanitarian Intervention: A Historical and Theoretical Overview', Acta Juridica Hungarica, 41:1-2 (2000), 88.

158 Such as the naval blockade of Naples in 1857 , the French expeditionary force sent to Lebanon and Syria in 1860-61, measures taken regarding misrule in Macedonia in 1903-08, and others.

159 P. Thornberry, International Law and the Rights of Minorities (Oxford: Clarendon Press, 1991), 43.

160 On Bluntschli's view on this matter, see Koskenniemi, The Gentle Civilizer of Nations, 77. 
161 Rolin-Jaequemyns, 'Le droit international et la phase actuelle de la question d'Orient', 295-385.

162 On Westlake's view on this question, see Koskenniemi, The Gentle Civilizer of Nations, 49.

163 Nys regards intervention in the Eastern Question as being of a 'special character' but not as justifying intervention. See Nys, Le droit international, vol. II, 232.

164 According to Rougier this lex specialis system was set up in the Treaty of Berlin. See Rougier, 'La théorie de l'intervention d'humanité', 475.

165 N. Onuf, 'Humanitarian Intervention: The Early Years', Center for Global Peace and Conflict Studies Symposium on the Norms and Ethics of Humanitarian Intervention, University of California, Irvine, 5 May 2000, 3. 